\title{
Activation of Dihaloalkanes by Thiol-dependent Mechanisms
}

\author{
F. Peter Guengerich \\ Department of Biochemistry and Center in Molecular Toxicology, Vanderbilt University School of Medicine, \\ Nashville, TN 37232-0146, USA
}

Received 28 October 2002

\begin{abstract}
Dihaloalkanes constitute an important group of chemicals because of their widespread use in industry and agriculture and their potential for causing toxicity and cancer. Chronic toxic effects are considered to depend upon bioactivation, either by oxidation or thiol conjugation. Considerable evidence links genotoxicity and cancer with glutathione conjugations reactions, and some aspects of the mechanisms have been clarified with 1,2dihaloalkanes and dihalomethanes. Recently the DNA repair protein $O^{6}$-alkylguanine transferase has been shown to produce cytotoxicity and genotoxicity by means of a thiol-dependent process with similarities to the glutathione reactions.
\end{abstract}

Keywords: $O^{6}$-Alkylguanine transferase, Bioactivation, Dihalomethanes, Ethylene dibromide, Glutathione, Mutations

\section{Introduction}

Halogenated chemicals have many uses in industrial processes, particularly as solvents. Dihalogenated alkanes are commonly used as solvents (e.g. $\mathrm{CH}_{2} \mathrm{Cl}_{2}$ ) and have also been used as precursors of vinyl monomers (e.g. $\mathrm{ClCH}_{2} \mathrm{CH}_{2} \mathrm{Cl}$ ), pesticides $\left(\mathrm{BrCH}_{2} \mathrm{CH}_{2} \mathrm{Br}\right)$, gasoline additives $\left(\mathrm{BrCH}_{2} \mathrm{CH}_{2} \mathrm{Br}\right)$, and synthetic building blocks. The toxicity of dihaloalkanes requires some special considerations. Industrial workers have the potential to be exposed to large amounts of some of these solvents in accidents, and deaths have resulted from acute toxicity (Letz et al., 1984). Another issue is the risk of cancer from long-term chronic exposure. For instance, $\mathrm{BrCH}_{2} \mathrm{CH}_{2} \mathrm{Br}$ was withdrawn from industrial use because of these concerns (Sun, 1984) and the potential of $\mathrm{CH}_{2} \mathrm{Cl}_{2}$ for causing human cancer is an ongoing problem in risk assessment (Andersen $e t$ al., 1987; Reitz et al., 1989).

*To whom correspondence should be addressed.

Tel: 1-615-322-2261; Fax: 1-615-322-3141

E-mail: guengerich@toxicology.mc.vanderbilt.edu
All halogenated hydrocarbons can be acutely toxic at high doses due to their general anesthetic properties. However, genotoxicity considerations relevant to cancer almost certainly involve bioactivation processes. Dihaloalkanes are bifunctional electrophiles and their activation shows some unusual properties. Conjugation of chemicals with the tripeptide glutathione (GSH) is usually a detoxication process in the body (Armstrong, 1997). However, most dihaloalkanes can be activated by either oxidation (cytochrome P450 (P450)) or by GSH conjugation by GSH transferases, e.g. $\mathrm{BrCH}_{2} \mathrm{CH}_{2} \mathrm{Br}$ (Fig. 1). Subsequently the chemistry involved in the GSH pathway has been extended to the DNA repair protein $O^{6}$-alkylguanine transferase (AGT).

\section{Ethylene Dibromide: Characterization of the Pathway to DNA Adducts}

Early work from the laboratories of Rannug (Rannug et al., 1978; Rannug and Beije 1979) and Breimer (van Bladeren et $a l ., 1979)$ indicated that the genotoxicity of ethylene dihalides was dependent upon cytosolic enzymes and not microsomal oxidation (e.g. P450). These basic results, repeated in our own laboratory (Guengerich et al., 1980), suggested that a GSH conjugation pathway such as that shown in Fig. 1 might be operative. Subsequently we were able to demonstrate the incorporation of radiolabel from both $\mathrm{BrCH}_{2} \mathrm{CH}_{2} \mathrm{Br}$ and $\mathrm{GSH}$ into DNA, either with GSH transferase or in rat hepatocytes (Ozawa and Guengerich, 1983). The major DNA adduct formed was demonstrated to be the $N^{7}$-guanyl adduct shown in Fig. 1, first by Raney $\mathrm{Ni}$ reduction to $N^{7}$-ethylguanine (Ozawa and Guengerich, 1983) and subsequently by NMR and mass spectrometry (Koga et al., 1986). This adduct was found to be the major one formed in liver or kidney DNA of rats treated with $\mathrm{BrCH}_{2} \mathrm{CH}_{2} \mathrm{Br}$ (Inskeep et al., 1986).

Further work indicated that GSH transferases yield the highest amount of GSH-alkyl-DNA adducts (in vitro) with $\mathrm{BrCH}_{2} \mathrm{CH}_{2} \mathrm{Br}$ compared to 1,3-dibromopropane and 1,4dibromobutane (Inskeep and Guengerich, 1984). These results suggested the possibility of anchimeric assistance in the 


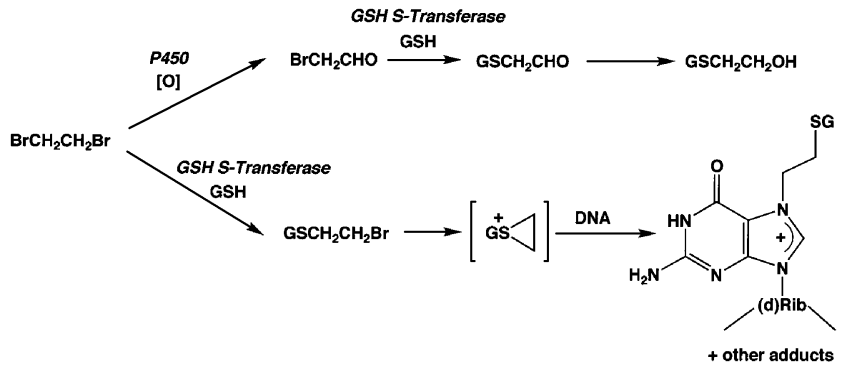

Fig. 1. Pathways for activation of EDB by oxidation and GSH conjugation.

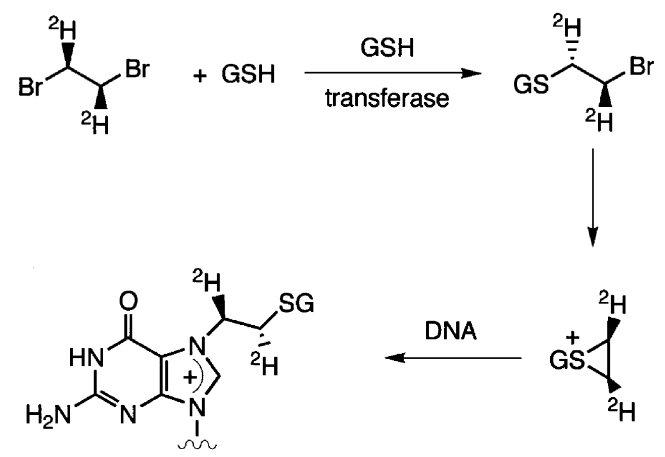

Fig. 2. Evidence for a role of an episulfonium ion intermediate in the activation of EDB using analysis of stereochemistry (Peterson et al., 1988).

mechanism of reaction of a GSH half-mustard with DNA. The mechanism was addressed in a series of experiments involving kinetics and stereochemistry (Peterson et al., 1988). In the kinetic analysis, the sulfur atom was found to be prerequisite for reaction, arguing for its role in activation and against a direct displacement (of the halide). Further, a free amino group was not required for reaction in a series of homologs of related cysteine half-mustards. A stereochemical experiment is outlined in Fig. 2. NMR analysis of the DNA adduct is only consistent with an odd number of $\mathrm{S}_{\mathrm{N}} 2$-type inversions (e.g., three in this case) and thus supports the scheme outlined in Fig. 2 (Peterson et al., 1988).

Some minor DNA adducts have also been characterized, being generated from $\mathrm{BrCH}_{2} \mathrm{CH}_{2} \mathrm{Br}$ or $\mathrm{GSCH}_{2} \mathrm{CH}_{2} \mathrm{Cl}$ in rat liver or DNA, respectively. These include $S$-[2-( $\left(N^{1}\right.$-adenyl)ethyl $]$ GSH (Kim et al., 1990) and $S$-[2-( $N^{2}$-guanyl)ethyl]GSH and $S$ [2-( $O^{6}$-guanyl)ethyl]GSH (Cmarik et al., 1992). Synthetic $N^{6}$ adenyl and $N^{4}$-cytidinyl adducts were prepared and used in analyses but neither of these adducts were detected in DNA treated with $\mathrm{GSCH}_{2} \mathrm{CH}_{2} \mathrm{Cl}$ (Cmarik et al., 1992).

\section{Processing of Ethylene Dibromide-GSH Adducts}

The $S$-[2-( $N^{\top}$-guanyl)ethyl]GSH adduct (Fig. 1) has a labile glycosidic bond and undergoes non-enzymatic depurination, with a half-life of 70-100 h in various rat tissues (Inskeep et

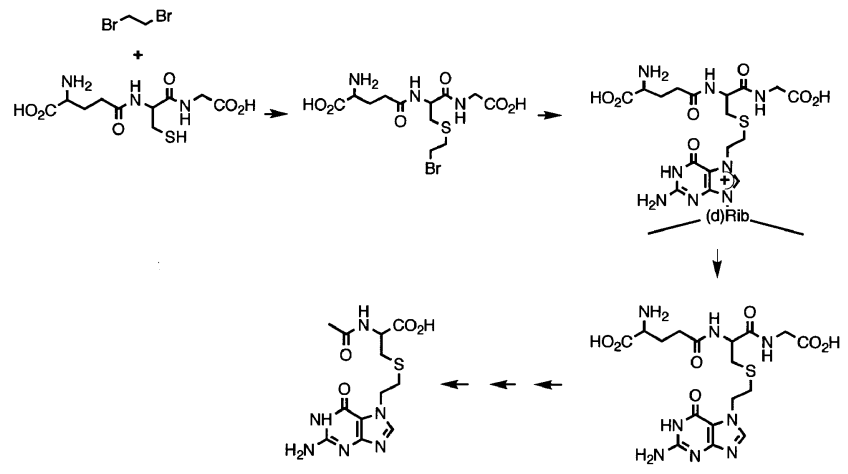

Fig. 3. Activation of EDB by GSH conjugation followed by nonenzymatic depurination (Inskeep et al., 1986) and enzymatic processing of the GSH conjugate to yield a mercapturic acid (Kim and Guengerich, 1989).

al., 1986). The adducted guanine is processed by the usual GSH degradation pathway to yield the mercapturic acid $S$-[2( $N^{7}$-guanyl)ethyl]- $N$-acetylcysteine, which is excreted in rat urine (Fig. 3) (Kim and Guengerich, 1989). The DNA $N^{7}$ guanyl adduct did not readily undergo ring-opening of the imidazole ring to a formamidopyrimidine derivative under physiological conditions (Cmarik et al., 1992).

The addition of GSH half-mustards $\left(\mathrm{GSCH}_{2} \mathrm{CH}_{2} \mathrm{X}\right.$, where $\mathrm{X}=$ halogen) to bacteria yielded DNA adducts and mutations (Humphreys et al., 1990). Considerations of the levels of DNA adducts and mutation frequency suggested that the $N^{7}$ guanyl adduct could explain the mutagenicity. In other experiments in which bacteriophage DNA was treated with $\mathrm{GSCH}_{2} \mathrm{CH}_{2} \mathrm{Cl}$ and then replicated in bacteria, the mutation spectrum was found to be dominated by GC to AT transitions (Cmarik et al., 1992). This signature argues strongly against a role for abasic sites (generated by depurination) as the basis of the mutations, in that a $\mathrm{G} \rightarrow \mathrm{T}$ transversion spectrum would have been expected (Sagher and Strauss, 1983). Oligonucleotides corresponding to a sequence of the bacteriophage DNA prone to mutation (Cmarik et al., 1992) were prepared with each of the three known GSH-ethylene conjugates that have been found with $\mathrm{BrCH}_{2} \mathrm{CH}_{2} \mathrm{Br}$ systems, i.e. the $N^{7}-, N^{2}$, and $O^{6}$-guanyl derivatives (Kim and Guengerich, 1997). In vivo experiments have not been done, but in vitro work has shown that all three of these adducts have the capability of blocking Escherichia coli polymerases (I and II) and causing at least some misincorporation (Kim and Guengerich, 1998). A more precise accounting of the contribution of each adduct to the overall mutagenicity in a cellular system is not yet available. However, it is of interest to note that recent experiments with an E. coli his reversion assay indicate that the expression of the DNA repair protein AGT (shown to act on the $S$-[2- $\left(O^{6}\right.$-guany)ethyl]GSH adduct) can partially reduce the extent of bacterial mutation (Liu et al., 2002).

Studies with other bacterial systems, Drosophila, and mammalian systems have also shown dominant $\mathrm{G} \rightarrow \mathrm{A}$ 


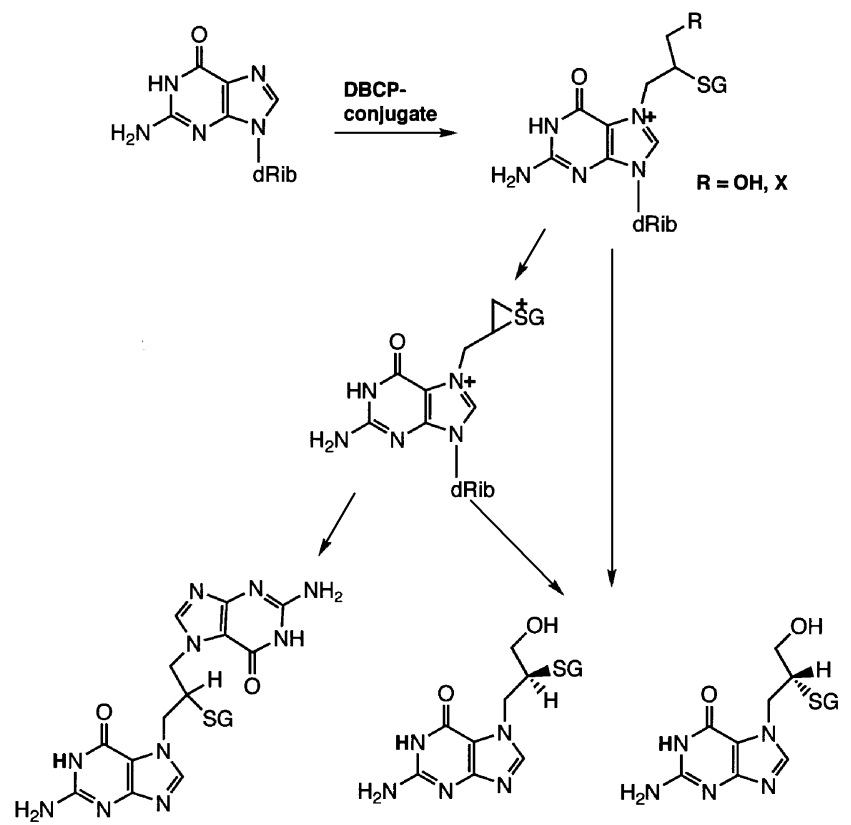

Fig. 4. DNA guanyl adducts derived from GSH conjugates of DBCP (Humphreys et al., 1991).

mutation spectra with $\mathrm{BrCH}_{2} \mathrm{CH}_{2} \mathrm{Br}$ (Foster et al., 1988; Ballering et al., 1994; Fossett et al., 1995; Graves et al., 1995). Recently we have used a yeast-based p53 mutation system, based on an ade reporter (Moshinsky and Wogan, 1997), to evaluate the mutation spectrum generated by $\mathrm{GSCH}_{2} \mathrm{CH}_{2} \mathrm{Cl}$. As with lacI (Cmarik et al., 1992) and the other systems, a strong $\mathrm{G} \rightarrow$ A pattern dominated (Valadez, J. G., and Guengerich, F. P., in preparation). One of the concerns in our earlier work (Cmarik et al., 1992) was the limited overlap between the mutation spectrum and the pattern of DNA damage (examined in an isolated oligonucleotide). With the p53 system, we were able to utilize a fluorescence-based ligation-mediated PCR method to analyze the patterns of DNA damage within the yeast at varying times after treatment. After $12 \mathrm{~h}$ the residual DNA damage (piperidinecleaved sites) showed a good match with the mutation spectrum. These results are interpreted to mean that the sequence selectivity of DNA repair (probably nucleotide excision repair) is a dominant factor in generating the observed mutation spectrum, at least in this system.

\section{DNA Adducts Formed with Other Dihaloalkanes (> 1-Carbon)}

In early work with the GSH-dependent activation, we reported evidence for activation of DBCP and tris-(2,3-dibromopropyl) phosphate, as well as $\mathrm{BrCH}_{2} \mathrm{CH}_{2} \mathrm{Br}$ (Inskeep and Guengerich, 1984). Subsequently we found a far lower level of DNA adduct formation in rat liver with $\mathrm{ClCH}_{2} \mathrm{CH}_{2} \mathrm{Cl}$ than $\mathrm{BrCH}_{2} \mathrm{CH}_{2} \mathrm{Br}$ (Inskeep et al., 1986). This halide order also holds in the activation of these dihaloethanes to mutagens in bacteria expressing mammalian GSH transferases (Wheeler $e t$ $a l .$, 2001a). Apparently the rate of conjugation to generate the initial half-mustard is an issue. DBCP reacts with GSH to generate a series of DNA adducts (Humphreys et al., 1991) (Fig. 4). These adducts are complex because of the potential trifunctional alkylating capability of this compound. Reaction of a DBCP-GSH conjugate with calf thymus DNA yielded the $N^{7}$-guanyl adducts plus the intra-strand crosslinked guanines shown in Fig. 4. We have not further evaluated the capability of the reagent to form interstrand crosslinks.

We can summarize the work in this area by stating that most 1,2-bifunctional alkanes are capable of causing genotoxic damage by this GSH-dependent pathway, with the leaving group order playing a major role in the extent of binding and biological activities (Thier et al., 1996; Wheeler et al., 2001b).

\section{Dihalomethanes}

The major pathways of metabolism of dihalomethanes were elucidated by Anders' group (Ahmed and Anders, 1976; Ahmed et al., 1977) and parallel those subsequently developed for dihaloethanes (Figs. 1, 5). The carcinogenicity of $\mathrm{CH}_{2} \mathrm{Cl}_{2}$ in mouse liver and lung has raised issues regarding risk assessment in regard to this commodity solvent (Anderson and Maronpot, 1993; Huff et al., 1996). Rats and hamsters are far less likely to develop tumors, and the question of the proper model for humans has been raised (Graves et al., 1995; Rhomberg, 1995).

The lack of saturability of tumor yield (with respect to dose of $\mathrm{CH}_{2} \mathrm{Cl}_{2}$ ) in mice had been suggested to imply that the GSH transferase-catalyzed conjugation is involved in $\mathrm{CH}_{2} \mathrm{Cl}_{2}$ tumorigenicity (Andersen et al., 1987; Reitz et al., 1989). However, experimental attempts to demonstrate $\mathrm{CH}_{2} \mathrm{Cl}_{2}$ bioactivation had been relatively inconclusive (van Bladeren $e t$ al., 1980; Green, 1983). Our laboratory, in collaboration with Ketterer's group, succeeded in expressing the rat theta class GSH transferase in the bacterial tester strain Salmonella typhimurium TA1535 (Their et al., 1993). Addition of $\mathrm{BrCH}_{2} \mathrm{CH}_{2} \mathrm{Br}, \mathrm{CH}_{2} \mathrm{Br}_{2}, \mathrm{CHBrCl}$, or $\mathrm{CH}_{2} \mathrm{Cl}_{2}$ to the bacteria yielded base pair mutations in the absence of any additional activation system (Fig. 6).

The conjugation of dihalomethanes with GSH yields formaldehyde (Fig. 5). However, formaldehyde was not mutagenic when added to this system (Thier et al., 1993). A series of studies with several GSH transferases and dihalomethanes shows a lack of correlation between formaldehyde production and mutagenicity, further arguing for another species, i.e. presumably a GSH conjugate (Wheeler et al., 2001b). The half-lives of $\mathrm{GSCH}_{2} \mathrm{X}$ conjugates are probably considerably less than of $\mathrm{GSCH}_{2} \mathrm{CH}_{2} \mathrm{X}$ homologs. $\mathrm{GSCH}_{2} \mathrm{CH}_{2} \mathrm{OAc}$ is quite stable (Wheeler et al., 2001a) while $\mathrm{GSCH}_{2} \mathrm{OAc}$ has a half-life of $\sim 12 \mathrm{~s}$ (Marsch $e t$ 


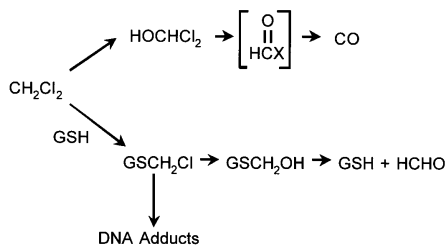

Fig. 5. Pathways for activation of $\mathrm{CH}_{2} \mathrm{Cl}_{2}$ by oxidation and GSH conjugation (Ahmed and Anders, 1976; Ahmed et al., 1977; Thier et al., 1993).

al., 2001). The work of Dekant and Anders (Hashmi et al., 1994) also suggests a short half-life for $\mathrm{GSCH}_{2} \mathrm{Cl}$.

Presumably DNA adducts are formed from $\mathrm{GSCH}_{2} \mathrm{X}$ compounds, in order to explain the bacterial mutagenicity (Fig. 6). Vuilleumeir used a bacterial GSH transferase to demonstrate the covalent binding of label from both $\mathrm{CH}_{2} \mathrm{Cl}_{2}$ and GSH to DNA (Kayser and Vuilleumier, 2001). Characterization of individual nucleoside and DNA adducts has been challenging because of the instability. We reacted synthetic $\mathrm{GSCH}_{2} \mathrm{OAc}$, a model for the GSH conjugate, with individual nucleosides and characterized four adducts (Fig. 7) (Their et al., 1993; Marsch et al., 2001). None of these are particularly stable, and we have spent considerable effort in developing rapid methods of DNA digestion and HPLC/mass spectrometry to analyze these. At this time we have tentative evidence that all of these can be formed in DNA treated with $\mathrm{GSCH}_{2} \mathrm{OAc}$ and that the guanine and thymidine adducts can be detected in DNA incubated with a bacterial GSH transferase, $\mathrm{CH}_{2} \mathrm{Br}_{2}$, and $\mathrm{GSH}$ (Marsch, G. A. and Guengerich, F. P., unpublished results).

The work has been extended to trihalomethanes by Pegram and his associates (DeMarini et al., 1997; Pegram et al., 1997). Although no DNA adducts have been characterized as of yet, the mechanism appears to parallel that shown for dihalomethanes. GSH conjugation yields formic acid and produces mutations in GSH transferase-expressing $S$. typhimurium tester strains, suggesting a mechanism analogous to that shown in Fig. 5.

\section{Activation of Dihaloalkanes by a DNA Repair Protein}

AGT is an enzyme found in organisms from bacteria to humans and has an important role in DNA repair, removing alkyl groups from the $\mathrm{O} 6$ atom of guanine to regenerate the normal base (Karran et al., 1979). However, several reports have appeared indicating that the expression of AGT (bacterial, rodent, or human) in E. coli increases the cytotoxicity and mutagenicity of $\mathrm{BrCH}_{2} \mathrm{CH}_{2} \mathrm{Br}$ and $\mathrm{CH}_{2} \mathrm{Br}_{2}$ in bacteria (Foster et al., 1988; Abril et al., 1995; Abril et al., 1997; Abril and Margison, 1999). The relationship with the previously documented GSH pathway was not clear from work with bacterial strains devoid of GSH or the $\mathrm{uvr}_{\mathrm{ABC}}$ repair
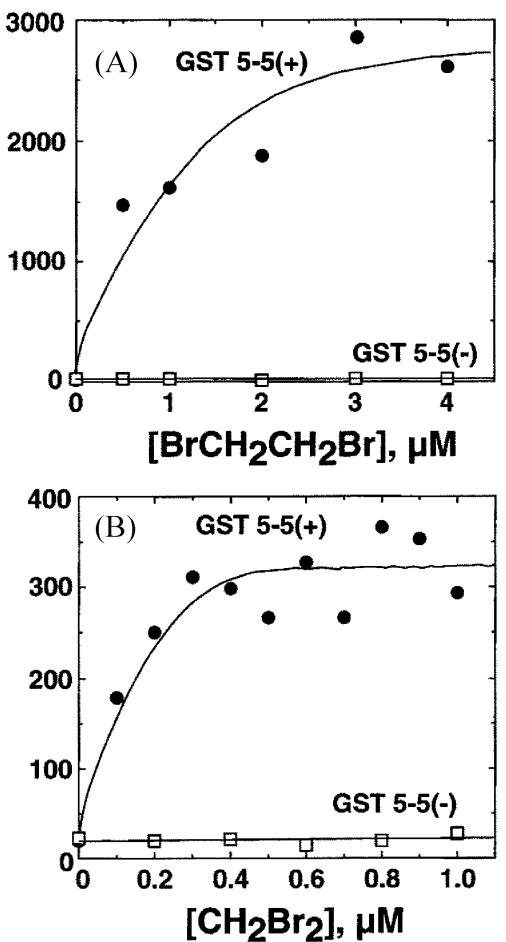

Fig. 6. Revertants in $S$. typhimurium TA1535 GST5-5 (+) ( $\lambda$, cDNA inserted in correct direction) and TA1535 GST5-5 (-) (o, cDNA inserted in opposite direction for negative control), as a function of the concentration of added $\mathrm{BrCH}_{2} \mathrm{CH}_{2} \mathrm{Br}$ (A) or $\mathrm{CH}_{2} \mathrm{Br}_{2}($ B) (Their et al., 1993).

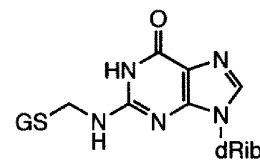

$S-\left[1-\left(N^{2}\right.\right.$-Deoxyguanosinyl)methyl] $] \mathrm{GSH}$

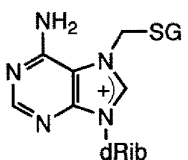

S-[1-( $N^{7}$-Deoxyadenosinyl)methyl] $)$ GSH<smiles>O=c1nc(NC[SeH])ccn1[18OH]</smiles>

$S-\left[1-\left(N^{4}\right.\right.$-Deoxycytidinyl)methyl] GSH

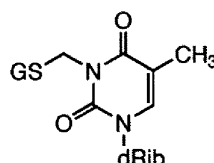

$S-\left[1-\left(N^{\beta}\right.\right.$-Thymidiny) $)$ methy $]$ GSH
Fig. 7. Nucleoside adducts characterized in the reaction of the model conjugate $\mathrm{GSCH}_{2} \mathrm{OAc}$ with nucleosides (Marsch et al., 2001).

system (Foster et al., 1988; Abril et al., 1995). In our preliminary collaborative work with the Pegg group, we found that expression of AGT in E. coli enhanced the mutagenicity of $\mathrm{BrCH}_{2} \mathrm{CH}_{2} \mathrm{Br}$ but decreased the mutagenicity of added $\mathrm{GSCH}_{2} \mathrm{CH}_{2} \mathrm{Cl}$ (Liu et al., 2002). The latter results are consistent with an at least partial role in mutagenesis for the $S$ [2-( $O^{6}$-guanyl)ethyl]GSH adduct (Cmarik et al., 1992; Kim and Guengerich, 1998), which was shown to be a substrate for AGT (Liu et al., 2002). 
(A)

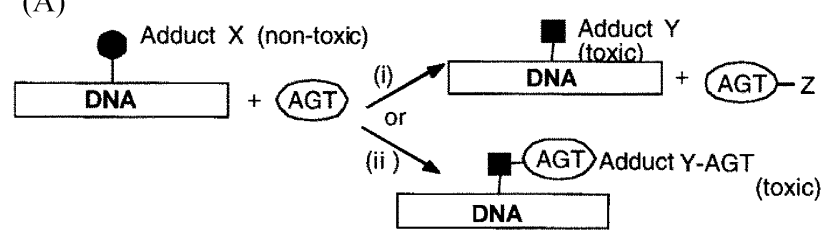

(B)

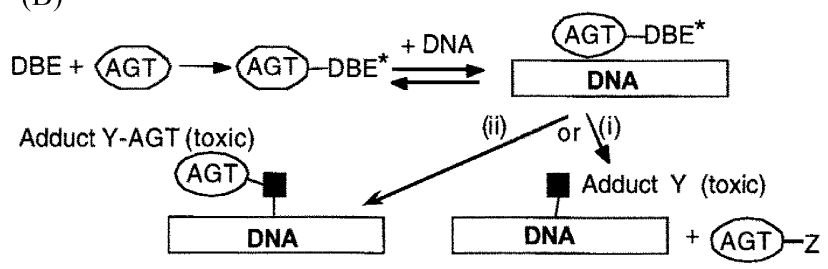

Fig. 8. Some possible explanations for the enhancement of EDB mutagenicity due to expression of AGT (Liu et al., 2002).

The enhancement of cytotoxicity and mutagenicity of dihaloalkanes by a DNA repair protein was an unusual finding, and a mechanism was not immediately obvious. Some of the possibilities that can be considered are shown in Fig. 8. In Part A, DNA reacts with $\mathrm{BrCH}_{2} \mathrm{CH}_{2} \mathrm{Br}$ to form an adduct " $X$ ", which then interacts with AGT to form either another adduct ("Y") or crosslinks AGT to the DNA. In Part B a crosslink (or a toxic product " $\mathrm{Y}$ ") is formed following the initial reaction of $\mathrm{BrCH}_{2} \mathrm{CH}_{2} \mathrm{Br}$ (DBE) with AGT. Other possibilities can be considered, such as the sequestration of AGT at a DNA- $\mathrm{BrCH}_{2} \mathrm{CH}_{2} \mathrm{Br}$ lesion to prevent other modes of repair.

The current evidence favors Pathway B of Fig. 8. Reaction of AGT with $\mathrm{BrCH}_{2} \mathrm{CH}_{2} \mathrm{Br}$ inhibited its subsequent activity in removing guanyl $O^{6}$-methyl groups, and the covalent addition adduction of the active site cysteine (Cys145) of AGT could be demonstrated using radioactive labeling and mass spectrometry (Liu et al., 2002). Further, the substitution C145A abolished the mutagenic response. Subsequent work showed the crosslinking of AGT to oligonucleotides in the presence of $\mathrm{BrCH}_{2} \mathrm{CH}_{2} \mathrm{Br}$ (Liu et al., 2002).

Similar mechanisms appear to be operative in the case of $\mathrm{CH}_{2} \mathrm{Br}_{2}$. Reaction of $\mathrm{BrCH}_{2} \mathrm{OAc}$ with AGT yielded a mass spectrum corresponding to the addition of $-\mathrm{CH}_{2} \mathrm{OAc}$, presumably to the active site Cys 145 because the $\mathrm{C} 145 \mathrm{~S}$ and C145A proteins yielded negative results.

\section{Conclusions}

A general theme of this work has been that thiol-dependent systems that normally have protective roles can be involved in the bioactivation of dihaloethanes and other bifunctional electrophiles (Oda et al., 1996; Their et al., 1996). The detrimental bioactivation is probably related to non-selectivity resulting from the low $\mathrm{p} K_{\mathrm{a}}$ values of GSH (due to GSH transferase) and AGT (both 6.6) (Graminski et al., 1989) (Guengerich, F. P., and Pegg, A. E., unpublished). A current summary of the activation of $\mathrm{BrCH}_{2} \mathrm{CH}_{2} \mathrm{Br}$ by the GSH pathway is presented in Fig. 9A, with potential genotoxicity of

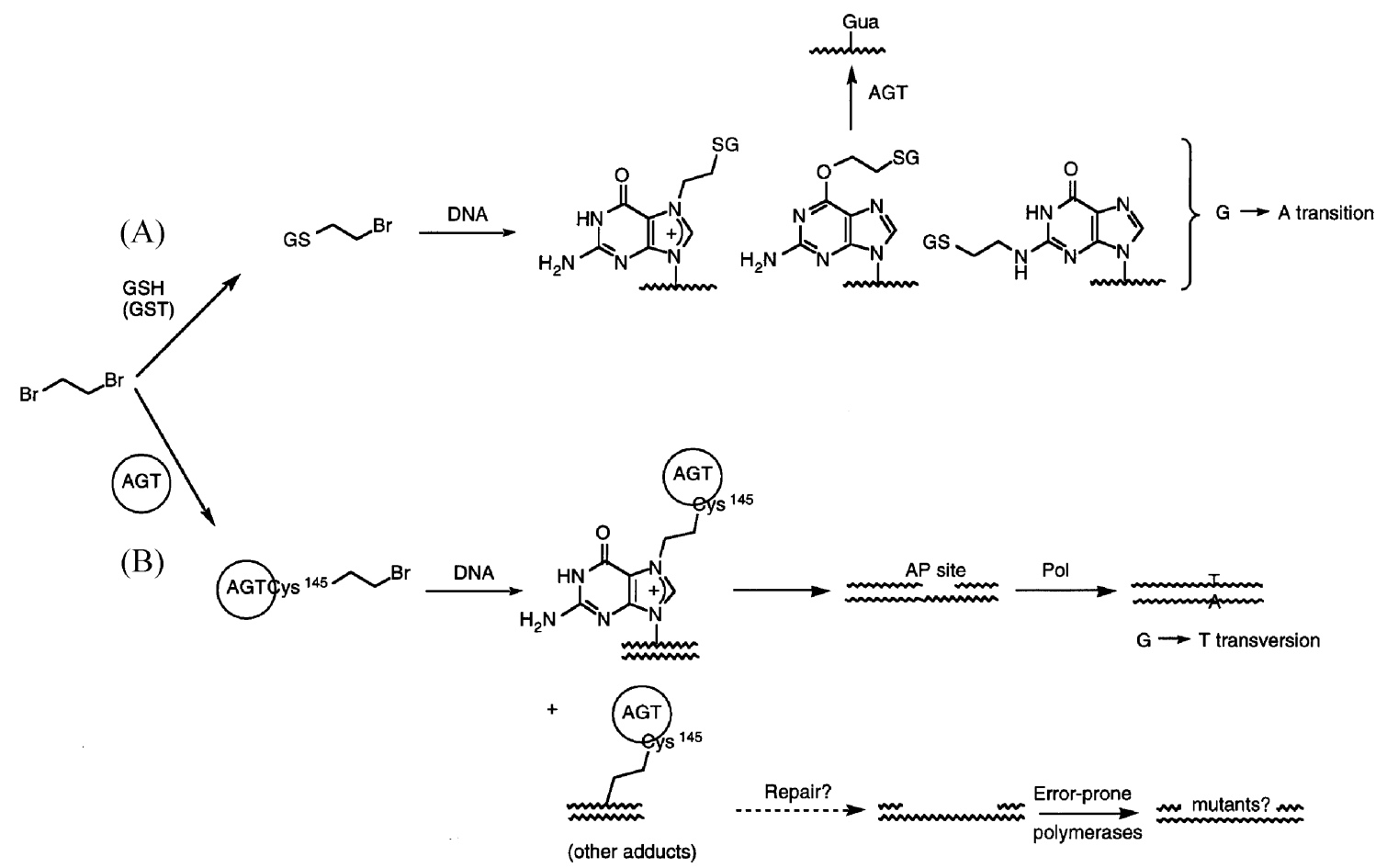

Fig. 9. Summary of postulated mechanisms of genotoxicity of EDB. A, GSH conjugation (Cmarik et al., 1992; Kim and Guengerich, 1998). B, AGT conjugation and DNA crosslinking (Liu et al., 2002). 
all three known guanine adducts (although the exact basis of the dominant $\mathrm{G} \rightarrow \mathrm{A}$ transition remains unknown). The AGT pathway (Fig. 9B) has considerable chemical similarity, at least in the early phases. The crosslinking of AGT to DNA can readily explain cytotoxicity, due to blockage of DNA polymerase. The mechanism of mutagenicity is less clear. One possibility is that, as with the $N^{7}$-guanyl adduct of the GSH pathway, depurination occurs and yields mutations. If this hypothesis is valid, AGT-dependent $\mathrm{BrCH}_{2} \mathrm{CH}_{2} \mathrm{Br}$ mutagenesis should yield a mutation spectrum dominated by $\mathrm{G}$ to $\mathrm{T}$ transversions (Sagher and Strauss, 1983), distinct from the G to A pattern seen in the GSH pathway (Part A) (Cmarik et al., 1992). However, a more complex pathway involving some error-prone repair process cannot be ruled out with the evidence currently available (Fig. 9B).

The above paradigms have also been generally applicable to dihalomethanes (Fig. 5), although the chemistry of reactions with the GSH conjugates differs considerably in its lack of $\mathrm{S}_{\mathrm{N}} 2$ character and yields very different DNA adducts than $\mathrm{BrCH}_{2} \mathrm{CH}_{2} \mathrm{Br}$ (Fig. 7). Several other bifunctional electrophiles also show enhancement of genotoxicity as the result of GSH conjugation, although the mechanisms are not well-established (e.g., butadiene diepoxide) (Their et al., 1995; Their et al., 1996).

Finally, the demonstration of both GSH transferase and AGT pathways of activation of dihaloethanes and dihalomethanes has been done largely in bacterial model systems because of the complexity of the mechanisms. However, the issue of which of these predominate in relevant mammalian systems must ultimately be addressed, i.e. under conditions where one or the other system is not artificially expressed or attenuated. In the future sensitive mass spectrometry assays and perhaps mutation spectra will be useful in such work.

Acknowledgments This research was supported in part by United States Public Health Service Grants R01 ES01590, R35 CA44353, R01 ES10546, and P30 ES00267. Individuals involved in the research in this laboratory include N. Ozawa, P. B. Inskeep, T. Shimada, N. Koga, L. A. Peterson, J. L. Cmarik (Nelson), D-H. Kim, T. Oida, W. G. Humphreys, MS. Kim, K-S. Min, R. Thier, M. Persmark, H. Shimamura, J. B. Wheeler, R. Mundkowski, G. A. Marsch, K. M. Williams, and J. G. Valadez. The AGT work has been done in collaboration with L. Liu and A. E. Pegg, Pennsylvania State University.

\section{References}

Abril, N., Luque-Romero, F. L., Prieto-Alamo, M.-J., Rafferty, J. A., Margison, G. P. and Pueyo, C. (1997) Bacterial and mammalian DNA alkyltransferases sensitize Escherichia coli to the lethal and mutagenic effects of dibromoalkanes. Carcinogenesis 18, 1883-1888.

Abril, N., Luqueromero, F. L., Prieto-Alamo, M. J., Margison, G.
P. and Pueyo, C. (1995) ogt alkyltransferase enhances dibromoalkane mutagenicity in excision repair-deficient Escherichia coli K-12. Mol. Carcinogen. 12, 110-117.

Abril, N. and Margison, G. P. (1999) Mammalian cells expressing Escherichia coli $O^{6}$-alkylguanine-DNA alkyltransferases are hypersensitive to dibromoalkanes. Chem. Res. Toxicol. 12, 544551.

Ahmed, A. E. and Anders, M. W. (1976) Metabolism of dihalomethanes to formaldehyde and inorganic halide. I. In vitro studies. Drug Metab. Dispos. 4, 357-361.

Ahmed, A. E., Kubic, V. L. and Anders, M. W. (1977) Metabolism of haloforms to carbon monoxide. I. In vitro studies. Drug Metab. Dispos. 5, 198-204.

Andersen, M. E., Clewell, H. J., III, Gargas, M. L., Smith, F. A. and Reitz, R. H. (1987) Physiologically based pharmacokinetics and the risk assessment process for methylene chloride. Toxicol. Appl. Pharmacol. 87, 185-205.

Anderson, M. W. and Maronpot, R. R. (1993) Methylene chlorideinduced tumorigenesis. Carcinogenesis 14, 787-788.

Armstrong, R. N. (1997) Glutathione transferases. In Biotransformation, Vol. 3, Comprehensive Toxicology (Guengerich, F. P., ed.) 307-327, Elsevier Science Ltd., Oxford.

Ballering, L. A. P., Nivard, M. J. M. and Vogel, E. W. (1994) Mutation spectra of 1,2-dibromoethane, 1,2-dichloroethane and 1-bromo-2-chloroethane in excision repair proficient and repair deficient strains of Drosophila melanogaster. Carcinogenesis 15, 869-875.

Cmarik, J. L., Humphreys, W. G., Bruner, K. L., Lloyd, R. S., Tibbetts, C. and Guengerich, F. P. (1992) Mutation spectrum and sequence alkylation selectivity resulting from modification of bacteriophage M13mp18 with $S$-(2-chloroethyl)glutathione. Evidence for a role of $S$-[2-( $N^{7}$-guanyl)ethyl]glutathione as a mutagenic lesion formed from ethylene dibromide. J. Biol. Chem. 267, 6672-6679.

DeMarini, D. M., Shelton, M. L., Warren, S. H., Ross, T. M., Shim, J. Y., Richard, A. M. and Pegram, R. A. (1997) Glutathione S-transferase-mediated induction of $\mathrm{GC} \rightarrow \mathrm{AT}$ transitions by halomethanes in Salmonella. Environ. Mol. Mutagen. 30, 440-447.

Fossett, N. G., Byrne, B. J., Tucker, A. B., Arbour-Reily, P., Chang, S. and Lee, W. R. (1995) Mutation spectrum of 2chloroethyl methanesulfonate in Drosophila melanogaster premeiotic germ cells. Mutat. Res. 331, 213-224.

Foster, P. L., Wilkinson, W. G., Miller, J. K., Sullivan, A. D. and Barnes, W. M. (1988) An analysis of the mutagenicity of 1,2dibromoethane to Escherichia coli: influence of DNA repair activities and metabolic pathways. Mutat. Res. 194, 171-181.

Graminski, G. F., Kubo, Y. and Armstrong, R. N. (1989) Spectroscopic and kinetic evidence for the thiolate anion of glutathione at the active site of glutathione $S$-transferase. Biochemistry 28, 3562-3568.

Graves, R. J., Coutts, C. and Green, T. (1995) Methylene chlorideinduced DNA damage: an interspecies comparison. Carcinogenesis 16, 1919-1926.

Green, T. (1983) The metabolic activation of dichloromethane and chlorofluoromethane in a bacterial mutation assay using Salmonella typhimurium. Mutat. Res. 118, 277-288.

Guengerich, F. P., Crawford, W. M., Jr., Domoradzki, J. Y., Macdonald, T. L. and Watanabe, P. G. (1980) In vitro activation of 1,2-dichloroethane by microsomal and cytosolic 
enzymes. Toxicol. Appl. Pharmacol. 55, 303-317.

Hashmi, M., Dechert, S., Dekant, W. and Anders, M. W. (1994) Bioactivation of $\left.{ }^{13} \mathrm{C}\right]$ dichloromethane in mouse, rat, and human liver cytosol: ${ }^{13} \mathrm{C}$ nuclear magnetic resonance spectroscopic studies. Chem. Res. Toxicol. 7, 291-296.

Huff, J., Bucher, J. and Barrett, J. C. (1996) Methylene chloride. Science 272, 1083-1084.

Humphreys, W. G., Kim, D. H. and Guengerich, F. P. (1991) Isolation and characterization of $N^{7}$-guanyl adducts derived from 1,2-dibromo-3-chloropropane. Chem. Res. Toxicol. 4, 445453.

Humphreys, W. G., Kim, D.-H., Cmarik, J. L., Shimada, T. and Guengerich, F. P. (1990) Comparison of the DNA alkylating properties and mutagenic responses caused by a series of $S$-(2haloethyl)-substituted cysteine and glutathione derivatives. Biochemistry 29, 10342-10350.

Inskeep, P. B. and Guengerich, F. P. (1984) Glutathione-mediated binding of dibromoalkanes to DNA: specificity of rat glutathione $S$-transferases and dibromoalkane structure. Carcinogenesis 5, 805-808.

Inskeep, P. B., Koga, N., Cmarik, J. L. and Guengerich, F. P. (1986) Covalent binding of 1,2-dihaloalkanes to DNA and stability of the major DNA adduct, $S$-[2- $\left(N^{7}-\right.$ guanyl)ethyl]glutathione. Cancer Res. 46, 2839-2844.

Karran, P., Lindahl, T. and Griffin, B. (1979) Adaptive response to alkylating agents involves alteration in situ of $O^{6}$-methylguanine residues in DNA. Nature 280, 76-77.

Kayser, M. F. and Vuilleumier, S. (2001) Dehalogenation of dichloromethane by dichloromethane dehalogenase/glutathione S-transferase leads to formation of DNA adducts. J. Bacteriol. 183, 5209-5212.

Kim, D. H. and Guengerich, F. P. (1989) Excretion of the mercapturic acid $S$-[2-( $N^{\top}$-guanyl)ethyl]- $N$-acetylcysteine in urine following administration of ethylene dibromide to rats. Cancer Res. 49, 5843-5851.

Kim, D.-H., Humphreys, W. G. and Guengerich, F. P. (1990) Characterization of $S$-[2-( $N^{1}$-adenyl)ethyl]glutathione formed in DNA and RNA from 1,2-dibromoethane. Chem. Res. Toxicol. 3, 587-594.

Kim, M.-S. and Guengerich, F. P. (1997) Synthesis of oligonucleotides containing the ethylene dibromide-derived DNA adducts $S$-[2-( $N^{7}$-guanyl)ethyl]glutathione, $S$-[2- $\left(N^{2}-\right.$ guanyl)ethyl]glutathione, and $S$-[2-( $O^{6}$-guanyl)ethyl]glutathione at a single site. Chem. Res. Toxicol. 10, 1133-1143.

Kim, M.-S. and Guengerich, F. P. (1998) Polymerase blockage and misincorporation of dNTPs opposite the ethylene dibromidederived DNA adducts $S$-[2-( $N^{\dagger}$-guanyl)ethyl]glutathione, $S$-[2( $N^{2}$-guanyl)ethyl $]$ glutathione, $\quad$ and $S$-[2-( $O^{6}$-guanyl)ethyl] glutathione. Chem. Res. Toxicol. 11, 311-316.

Koga, N., Inskeep, P. B., Harris, T. M. and Guengerich, F. P. (1986) $S$-[2-( $N^{\top}$-Guanyl)ethyl]glutathione, the major DNA adduct formed from 1,2-dibromoethane. Biochemistry 25, 21922198.

Letz, G. A., Pond, S. M., Osterloh, J. D., Wade, R. L. and Becker, C. E. (1984) Two fatalities after acute occupational exposure to ethylene dibromide. J. Am. Med. Assoc. 252, 2428-2431.

Liu, L., Pegg, A. E., Williams, K. M. and Guengerich, F. P. (2002) Paradoxical enhancement of the toxicity of 1,2dibromoethane by $O^{6}$-alkylguanine-DNA alkyltransferase. $J$. Biol. Chem. 277, 37920-37928.
Marsch, G. A., Mundkowski, R. G., Morris, B. J., Manier, M. L., Hartman, M. K. and Guengerich, F. P. (2001) Characterization of nucleoside and DNA adducts formed by $S$-(1acetoxymethyl)glutathione and implications for dihalomethaneglutathione conjugates. Chem. Res. Toxicol. 14, 600-608.

Moshinsky, D. J. and Wogan, G. N. (1997) UV-induced mutagenesis of human $\mathrm{p} 53$ in a vector replicated in Sacharomyces cerevisiae. Proc. Natl. Acad. Sci. USA 94, 2266-2271

Oda, Y., Yamazaki, H., Thier, R., Ketterer, B., Guengerich, F. P. and Shimada, T. (1996) A new Salmonella typhimurium NM5004 strain expressing rat glutathione S-transferase 5-5: use in detection of genotoxicity of dihaloalkanes using an SOS/ ити test system. Carcinogenesis 17, 297-302.

Ozawa, N. and Guengerich, F. P. (1983) Evidence for formation of an $S$-[2-( $N^{7}$-guanyl)ethyl]glutathione adduct in glutathionemediated binding of 1,2-dibromoethane to DNA. Proc. Natl. Acad. Sci. USA 80, 5266-5270.

Pegram, R. A., Andersen, M. E., Warren, S. H., Ross, T. M. and Claxton, L. D. (1997) Glutathione S-transferase-mediated mutagenicity of trihalomethanes in Salmonella typhimurium: contrasting results with bromodichloromethane and chloroform. Toxicol. Appl. Pharmacol. 144, 183-188.

Peterson, L. A., Harris, T. M. and Guengerich, F. P. (1988) Evidence for an episulfonium ion intermediate in the formation of $S$-[2-( $N^{7}$-guanyl)ethyl]glutathione in DNA. J. Am. Chem. Soc. 110, 3284-3291.

Rannug, U. and Beije, B. (1979) The mutagenic effect of 1,2dichloroethane on Salmonella typhimurium. II. Activation by the isolated perfused rat liver. Chem.-Biol. Interact. 24, 265285.

Rannug, U., Sundvall, A. and Ramel, C. (1978) The mutagenic effect of 1,2-dichloroethane on Salmonella typhimurium. I. Activation through conjugation with glutathione in vitro. Chem.-Biol. Interact. 20, 1-16.

Reitz, R. H., Mendrala, A. and Guengerich, F. P. (1989) In vitro metabolism of methylene chloride in human and animal tissues: use in physiologically-based pharmacokinetic models. Toxicol. Appl. Pharmacol. 97, 230-246.

Rhomberg, L. (1995) Use of quantitative modelling in methylene chloride risk assessment. Toxicology 102, 95-114.

Sagher, D. and Strauss, B. (1983) Insertion of nucleotides opposite apurinic/apyrimidinic sites in deoxyribonucleic acid during in vitro synthesis: uniqueness of adenine nucleotides. Biochemistry 22, 4518-4526.

Sun, M. (1984) EDB contamination kindles federal action. Science 223, 464-466.

Thier, R., Müller, M., Taylor, J. B., Pemble, S. E., Ketterer, B. and Guengerich, F. P. (1995) Enhancement of bacterial mutagenicity of bifunctional alkylating agents by expression of mammalian glutathione S-transferase. Chem. Res. Toxicol. 8, 465-472.

Thier, R., Pemble, S. E., Taylor, J. B., Humphreys, W. G., Persmark, M., Ketterer, B. and Guengerich, F. P. (1993) Expression of mammalian glutathione $S$-transferase $5-5$ in Salmonella typhimurium TA1535 leads to base-pair mutations upon exposure to dihalomethanes. Proc. Natl. Acad. Sci. USA 90, 8576-8580.

Thier, R., Pemble, S., Kramer, H., Taylor, J. B., Guengerich, F. P., and Ketterer, B. (1996) Human glutathione S-transferase T1-1 
enhances mutagenicity of 1,2-dibromoethane, dibromomethane, and 1,2,3,4-diepoxybutane in Salmonella typhimurium. Carcinogenesis 17, 163-166.

van Bladeren, P. J., Breimer, D. D., Rotteveel-Smijs, G. M. T. and Mohn, G. R. (1980) Mutagenic activation of dibromomethane and diiodomethane by mammalian microsomes and glutathione $S$-transferases. Mutat. Res. 74, 341-346.

van Bladeren, P. J., van der Gen, A., Breimer, D. D. and Mohn, G. R. (1979) Stereoselective activation of vicinal dihalogen compounds to mutagens by glutathione conjugation. Biochem.
Pharmacol. 28, 2521-2524.

Wheeler, J. B., Stourman, N. V., Armstrong, R. N. and Guengerich, F. P. (2001a) Conjugation of haloalkanes by bacterial and mammalian glutathione transferases: mono- and vicinal dehaloethanes. Chem. Res. Toxicol. 14, 1107-1117.

Wheeler, J. B., Stourman, N. V., Thier, R., Dommermuth, A., Vuilleumier, S., Rose, J. A., Armstrong, R. N. and Guengerich, F. P. (2001b) Conjugation of haloalkanes by bacterial and mammalian glutathione transferases: mono- and dihalomethanes. Chem. Res. Toxicol. 14, 1118-1127. 